\title{
Desenvolvimento familiar e Casa Comum
}

\author{
Family development and cohousing \\ Desarrollo familiar y hogar común
}

Odirlei Arcangelo Lovo

ORCID: https://orcid.org/0000-0003-0576-9284 Universidade Federal de Rondônia, Brasil E-mail: oalovo@gmail.com

\begin{abstract}
Resumo
O desenvolvimento em família deve acontecer em perspectivas de processos de alteridade, reciprocidade e subsidiariedade, reconhecendo as relações como pontos fortes a serem desenvolvidas. Objtivo deste artigo é elucidar a criação, nossa casa comum, como ato de amor, no qual as pessoas, mediante a parentalidade e o trabalho suscitam a sociabilidade e a economicidade para que assim se possa administrar, como base nos subsidios, as necessidades e as possibilidades. Compreender o ser humano enquanto agente que possibilita a praxis necessária para o cuidado da Casa Comum tem sido o proposito pelo qual se desenvolve pesquisas narrativas com o intuito de desenvolver o sentido antropoligco que sucita a pessoa como o administrador do mundo, para esta pesquisa de aborgadagem qualitativa e narrativa, é utilizado os documentos da Doutrina Social da Igreja Católica bem como documentos que apresentam a vivência familiar. Conclui-se que cada família é, gesto concreto à forma como vive a família humana, a consciência de ser os administradores da casa comum, eleva o ser humano a práxis de administrar.
\end{abstract}

Palavras-chave: Criação; Cuidar; Família; Essência administrativa; Casa comum; Homo Ad-minister.

\begin{abstract}
Family development must take place from the perspective of processes of alterity, reciprocity and subsidiarity, recognizing relationships as strengths to be developed. The purpose of this article is to elucidate the creation, our common home, as an act of love, in which people, through parenting and work raise sociability and economy so that, based on subsidies, needs and possibilities. Understanding the human being as an agent that enables the necessary praxis for the care of the Common Home has been the purpose for which narrative research has been developed with the aim of developing the anthropological sense that succincts the person as the administrator of the world, for this approach research qualitative and narrative, the documents of the Social Doctrine of the Catholic Church are used, as well as documents that present the family experience. It is concluded that each family is, a concrete gesture to the way the human family lives, the awareness of being the administrators of the cohousing, elevating the human being to the praxis of administration.
\end{abstract}

Keywords: Creation; Take care; Family; Administrative essence; Cohousing; Homo Ad-minister.

\section{Resumen}

El desarrollo familiar debe darse desde la perspectiva de procesos de alteridad, reciprocidad y subsidiariedad, reconociendo las relaciones como fortalezas a desarrollar. El propósito de este artículo es dilucidar la creación, nuestra casa común, como un acto de amor, en el que las personas, a través de la paternidad y el trabajo, elevan la sociabilidad y la economía para que, a partir de subsidios, necesidades y posibilidades. Entender al ser humano como un agente que habilita la praxis necesaria para el cuidado de la Casa Común ha sido el propósito para el cual se ha desarrollado la investigación narrativa con el objetivo de desarrollar el sentido antropológico que sucinta a la persona como administradora del mundo, por En este enfoque de investigación cualitativa y narrativa, se utilizan los documentos de la Doctrina Social de la Iglesia Católica, así como documentos que presentan la experiencia familiar. Se concluye que cada familia es, un gesto concreto al modo de vida de la familia humana, la conciencia de ser los administradores de la casa común, elevando al ser humano a la praxis de la administración.

Palabras clave: Creación; Cuídate; Familia; Esencia administrativa; Casa común; Homo Ad-minister.

\section{Introdução}

Este é o momento de pensar a parentalidade enquanto fonte de humanidade. Um convite à reflexão sobre o quanto a pessoa e sua parentalidade contribuem com a Casa Comum ou o quanto a parentalidade está focada em explorar predatoriamente os recursos naturais e as próprias pessoas. Quando se propõe a pensar a família humana, insere-se nas 
dimensões de economicidade, de sociabilidade e de parentalidade, para assim, ser capaz de desenvolver práxis que elevem nossas possibilidades de cuidado, desenvolvimento e sustentabilidade, tomando por base as possibilidades, as necessidades e os subsídios que estão à disposição.

Zelar da dignidade dada à vida humana é aceitar que toda criança tem direito à vida, isto é, direito a ser tutelada para que possa se tornar autônoma, agir em livre-arbítrio, administrar e cocriar a casa comum na liberdade da vida que se edifica em família, na sociabilidade, na parentalidade e na economicidade.

O ser humano, em família, é o ato administrativo e cocriador do mundo que vivemos, por isso, a essência administrativa, Dom dos Dons, dado à vida humana, habita o mais íntimo de cada pessoa. É mediante a essência administrativa que o ser humano é capacitado a cultivar e guardar o Jardim, esse ambiente onde o ser humano e chamada a se desenvolver.

\section{Metodologia}

A interdisciplinaridade desta pesquisa possibilita avançar entre os limiares das ciências administrativa e Teológica, portanto, com base em metodológica adequada se compreende o ser humano, em sua liberdade e desenvolvimento, como agente ativo que administra e cocria o mundo que vivemos. Fazer, segundo a vontade de Deus - esponsalidade, significa administrar a criação e, por isso, há práxis teológica e, à medida que se faz teologia, compreende-se como administrar a Criação e, neste sentido, subentende-se que "a vida que Deus oferece ao homem, é um dom, pelo qual Deus participa algo de Si mesmo à sua criatura" (João Paulo II, 1995, nº 34).

O ser humano, mediante a essência administrativa, se desenvolve e se torna, em livre-arbítrio, o ato administrativo na criação. Enseja-se que a esperança é constitutiva da ação necessária em perspectiva do modo de agir esperançado, compreendese que "a interpretação correta do conceito de ser humano como senhor do universo é entendê-lo no sentido de administrador responsável" (Francisco, 2015, n 116).

A pesquisa, utiliza-se de análise documental e narrativas para elucidar questões relacionadas ao ser humano, vertendose a compreendê-lo, segundo pesquisa qualitativa e reflexiva, como administrador da Criação. Mediante os procedimentos metodológicos de aspectos narrativos, utilizou-se de pesquisa documental e conduziu-se às possibilidades, às interpretações e às informações, na afirmativa que "uma narrativa é composta por uma sequência singular de eventos, estados mentais, ocorrências envolvendo seres humanos como personagens ou autores" (Bruner, 2002, p. 46).

A narrativa, método utilizado para esta pesquisa, explora, aprofunda e sugere respostas às particularidades, onde a realidade não pode, ou não deve ser quantificada, particularizando ainda que, "Uma verdadeira pesquisa narrativa é um processo dinâmico de viver e contar histórias, e reviver e recontar histórias" (Clandini \& Conelly, 2011, p. 18).

O universo dos significados, das aspirações, das crenças, dos valores e práxis humana é explorado e para a pesquisa utilizou-se dois núcleos fundamentais de dados, textos e informações, a saber: os documentos que constituem a (DSI) Doutrina Social da Igreja; e os documentos que elucidam o projeto, a vivência e a dinâmica familiar, segundo a igreja católica. O uso desses dois núcleos tem por base, sua universalidade, isto é, são documentos que se destinam a toda a humanidade, diante dos dons de cada pessoa.

\section{Resultados e Discussão}

A Criação de Deus versa seu propósito à vida humana, enquanto imagem de Si que habita a humanidade, e segundo a essência administrativa, permite compreender e edificar a práxis necessária para o desenvolvimento da vida. Implica dizer que o humano é uma tarefa dada a si mesmo, sua atitude é práxis por isso, "sede fecundos, multipliquem-se" (Gn 2,28) é resultante da ação de "cultivar e guardar" (Gn 2,15).

Ressalta-se que, em qualquer ambiente, a administração é uma realidade humana, e que de oportuno se faz Teologia 
desse dado. O dom da Administração é tratado, diante da essência administrativa, o Si de Deus que habita o íntimo humano, o faz compreender o chamado e o mandado à ser imagem e semelhança do Criador, significando a própria Casa Comum. Neste sentido, apresentar-se elementos e reflexões que contribuem para compreender as teologias sobre a família e sobre o cuidado para com a Casa Comum

\subsection{Alteridade e reciprocidade de ser em família}

A vida humana é compreendida em seu sentido de administrar a criação; o ser humano coloca-se sempre a transformar as coisas que permanecem diante da contingência da criação em desenvolvimento. É por intermédio, do agir, da educação, da cultura e da palavra, que a criação se desperta para o ritmo e práxis, desta forma o ser humano dá significado, finalidade e sentido, e com isso exerce a missão que lhe foi confiada.

Essa capacidade de significar, cultivar, guardar, ir/agir e proliferar e que se atenua como elementos da essência administrativa, e mediante a esponsalidade com o Criador, desperta para a potência de ser o administrador e cocriador da Casa Comum, “quem foi criado/a para ser sua imagem é, também, 'de sua descendência' (At 17,28.29)" (Moltmann, 1993, p. 133).

Devem ser observadas as ações em parentalidade com a família humana, a resposta humana, como ser livre que pode amar, e usar a inteligência para dar continuidade à Criação em desenvolvimento, em perspectiva de que a "semelhança de Deus significa, em primeiro lugar, a relação de Deus para com a pessoa e somente então a partir disso a relação da pessoa para com Deus" (Moltmann, 1993, p. 318).

A concepção humana, no mandado a "cultivar e guardar o Jardim" (Gn 2,15), é precedida pelo Dom da essência administrativa, um Si de Deus, que habita o íntimo humano e possibilita exercer o mandado recebido: "o ser da pessoa brota dessa relação de Deus para com a pessoa e consiste nessa relação, e não nessa ou naquela qualidade que diferencia a pessoa de outros seres viventes" (Moltmann, 1993, p. 318), dessa forma, é possível afirmar que, "A fé não é a fonte de conhecimento teológico; não produz os dados da revelação histórica; é um estado de radical receptividade. A fé recebe aquilo que a revelação dá. É o lado receptor de um relacionamento criado pelo Espírito de Deus.” (Braaten, 1993, p. 39).

A eternidade e a criatura humana estão submersas na esponsalidade com o Criador, fonte da essência administrativa que há no humano e que conclama cada pessoa à práxis de amor na criação, "imagem viva de Deus, o homem foi querido pelo seu Criador como rei e senhor. 'Deus fez o homem [...] de forma tal que pudesse desenhar sua função de rei da terra. (...) $\mathrm{O}$ homem foi criado à imagem d'Aquele que governa o universo" (João Paulo II, 1995, nº 52).

A relação humana na Criação revela também a 'solidão original' sob a qual se constitui caos e o vazio de um ser que não aceita ser criatura. A solidão original produz a inconsciência e a negligência do ato de amor, elementos que colocam o Criador e a criação à prova, com a alegação do por que criar, quando não se é capaz de fazer em plenitude? Sob estas alegações o indivíduo se opõe a um reino em desenvolvimento, onde a contingência evidencia, a cada pessoa, sua missão de administrar e cocriar os mistérios.

A contingência da criação não desfaz a plenitude do Reino Esperançado, a criação necessita de desenvolvimento. Então, dizer de uma criação necessitada de desenvolvimento, ou de um reino contingente, é anunciar a vida humana, para que essa possa desenvolver o reino segundo a esponsalidade com o Criador e, tendo por base, as coisas possibilitadas.

Cristo é a imagem humana, para administrar e cocriar a Criação em desenvolvimento, bem como a caminho da plenitude, onde o bom, o belo e o verdadeiro será tudo em todos para que todos sejam um. Nesse sentido cada pessoa é templo do Espírito Santo, e para entrar no templo é necessário: alteridade, relação, respeito e práxis. Assim, a vida e vivência das pessoas, estabelecem com o próximo, com a criação, e com Criador, uma unidade.

A Criação, como um fazer único e seu resultado deixam de existir. Coloca-se em primeiro plano a eterna relação entre criador e criatura, compreendida como a esponsalidade. Dizer que a criação é um ato perpétuo é assinalar que este ato continua 
criando, e torna toda pessoa templo do Espírito Santo, portando cada pessoa é chamada a ser o administrador e cocriador da Casa Comum.

\subsection{A criação é ato perpétuo}

A esponsalidade possibilita a essência administrativa, práxis de vida e vivência humana, e assim "os operários e os artesãos 'asseguram uma criação perpétua' (Sir 38, 34)" (Francisco, 2015, n 124), e o ser humano, edificado do húmus da terra, para ser em livre-arbítrio e mediante o agir humano, o administrador da Criação.

A dimensão de sociabilidade humana estabelece uma aliança sócio afetiva em função do desejo da parentalidade. Todavia, a parentalidade deve se conduzir à família humana, na economicidade dos filhos, porque "criados à imagem e semelhança de Deus como ‘unidade dos dois', ambos foram chamados a um amor de caráter esponsal” (João Paulo II, 1988, nº 23).

A sociabilidade humana é o ambiente onde o amor se torna pleno; por isso, "o matrimônio, na verdade, não é um acontecimento que diz respeito só a quem se casa. Por sua própria natureza é também um fato social, que compromete os esposos ante a sociedade" (João Paulo II, 1981, n 68). A parentalidade tem seu despertar para a família humana, no conjunto de relações que se originam na relação conjugal e se torna fonte de esperança para o reino.

A parentalidade é um projeto de conjugalidade, e primeiro se faz pela união de duas famílias, que se projetam na unidualidade da relação conjugal dos filhos, agora capazes de serem cônjuges, pai/mãe. É recíproco o compromisso dos cônjuges para com a família humana bem como o compromisso da família humana para com os cônjuges.

A sociedade que se torna fria e impessoal sempre que se inclina em uma das vertentes, ou seja, uma sociedade que abandona a dignidade da pessoa para viver o controle econômico, social e parental, termina por romper com a economicidade, a sociabilidade e a parentalidade humana e tende a viver sob sistemas de controles Estatizantes, em que o modelo, a regra e a lei são superiores à dignidade da pessoa, deste moto se apresenta que "Quando é dado ao não necessário, o valor absoluto, esse ocupa a dimensão de sociabilidade no individuo avarento e, por fim a dimensão familiar, restando-lhe como opção o trabalho, não no sentido criativo, cocriador e administrador, mas no sentido de exploração e acumulação predatória" (Lovo, 2020, p. 58)

A obsessão por apossar-se do que é comum, promove o ser humano, enquanto senhor do sistema de controle. Desvinculados entre si, as potencialidades de sociabilidade, de economicidade e de parentalidade terminam por tornarem-se submissos aos sistemas de controles - estrutura social, - perdendo em si a possibilidade da essência administrativa, em se tratando de Teologia, ela "não é, com efeito, teológica a não ser que veja cada objeto particular como originário de Deus e dirigindo-se para Ele" (Rahner, 1969, p. 22).

A esponsalidade com o Criador possibilita a essência administrativa, isto é, a necessidade da Teologia para aprender administrar e cocriar o mundo, "é unicamente quando interrogamos sobre as razões últimas que a interrogação é filosófica" (Rahner, 1969, p. 22), neste sentido, o ser humano não se prende só ao conhecimento - gnóstico, mas à práxis decorrente da essência administrativa, "porque a transcendência que somos e fazemos aproxima a nossa existência e a de Deus, e ambas como mistério" (Rahner, 1969, p. 66), é com base nas interrogações e nos mistérios que somos chamados a administrar e a cocriar o mundo que vivemos, deste modo, Lovo, (2021, p. 190) elucida que "Administrar é dar possibilidades ao que existe, é avançar sobre o que não é possibilitado, mas que se alça em ser possibilitado no futuro, pela ação humana"

Nesse momento, percebe-se que a fraternidade jorra onde existe liberdade, uma liberdade que possibilita a edificação do bem comum, da subsidiariedade e da solidariedade, e por isso se é capaz e não condenado a amar. Amar é ser família humana, em esponsalidade, e isso se faz diante da correspondência e relação, "A reciprocidade do amor é exigida pelo mandamento que Jesus mesmo define novo e Seu: 'como eu vos tenho amado, assim também vós deveis amar-vos uns aos outros' (Jo 13,34)" (João Paulo II, 2004, nº 32). 
Administrando a obra, da qual é parte, "O mandamento do amor recíproco traça a via para viver em Cristo [...] e transformar com Ele a história até ao seu pleno cumprimento na Jerusalém Celeste" (João Paulo II, 2004, n 32 ), a criação, nossa casa comum, se torna relação prospera e sustentável em face ao agir humano que revela em si mesmo, relação de cuidado com a criação, igualmente, "É um dever desempenhar de modo eficiente a atividade de produção dos bens, pois do contrário se desperdiçam recursos; mas não é aceitável um crescimento econômico obtido em detrimento dos seres humanos, de povos inteiros e de grupos sociais, condenados à indigência e à exclusão.” (João Paulo II, 2004, nº 332).

Quando o humano decide pegar para si o fruto que pertence ao espaço/tempo comum, rompe com a Graça e se prende ao próprio espaço/tempo, torna-se um idólatra de suas posses e, ao mesmo tempo, torna-se insustentável na egolatria de seus atos. É de se notar que “'desenvolvimento autêntico' 'deve ser integral, quer dizer, promover todos os homens e o homem todo"” (Bento XVI, 2009, nº 18).

O ser humano leva consigo a inscrição das leis da eternidade em seu íntimo, de tal modo que "A dimensão moral da economia faz tomar como finalidades indivisíveis, nunca separadas e alternativas, a eficiência econômica e a promoção de um desenvolvimento solidário da humanidade" (João Paulo II, 2004, n 332). O trabalho de cada pessoa contribui para a desenvolvimento do ambiente saudável de vida, é com o trabalho que o ser humano da continuidade à Criação.

\subsection{A parentalidade e o trabalho}

Não se domina a vida, mas a continuidade do existir da vida é produto de decisões humanas; por vezes a humanidade se coloca sob o pensamento de que pode "dispor arbitrariamente da terra, submetendo-a sem reservas à sua vontade, como se ela não possuísse uma forma própria e um destino anterior que Deus lhe deu, e que o homem pode, sim, desenvolver, mas não deve trair" (João Paulo II, 1991, n 37), ainda é notório que "A justiça há de respeitar-se, não só na distribuição da riqueza, mas também na estrutura das empresas em que se exerce a atividade produtiva" (João XXIII, 1961, nº 82).

Deus se faz participante da história de cada pessoa, diante do livre-arbítrio humano, ou seja, na vontade humana que deseja projetar a imagem de Deus à criação, "Na verdade, exige a natureza que os homens, no exercício da atividade produtiva, encontrem possibilidade de empenhar a própria responsabilidade e aperfeiçoar o próprio ser” (João XXIII, 1961, nº 82).

A avareza faz com que o humano "em vez de realizar o seu papel de colaborador de Deus na obra da criação, o homem substitui-se a Deus e, desse modo, acaba por provocar a revolta da natureza, mais tiranizada que governada por ele" (João Paulo II, 1991, n 38). Quando se fala da revolta da natureza, se pontua que o ser humano, destruindo as plantas e seres, provoca desequilíbrios no Jardim, nossa Casa Comum.

Toda a história humana é e será proveniente da potência de ter filhos, e é na parentalidade que se faz sua edificação, planejando e zelando do ato de ser pai/mãe. Fazer a vontade do Criador não está unicamente para a educação dos filhos, mas para um conjunto que envolve a economicidade, a sociabilidade e a parentalidade; assim, esse conjunto e suas relações afirmará o proposito pelo qual as pessoas se unem para ser uma nova família e ao mesmo tempo caminhar no sentido de superar os desafios apresentados por dinâmicas socioeconômicas que nem sempre favorecem a vivência familiar, de modo que "estudar a relação entre planejamento da parentalidade e o trabalho é investigar o modo como as pessoas legitimamente incluem as preocupações socioeconômicas no planejamento de ter filhos, como também, questionar quando a excessiva preocupação com o econômico transforma a família em uma instituição fechada à procriação" (Sanches, Rocha \& Lovo, 2008, p. 233).

A dinâmica de vida e da vivência humana possibilita compreender que o "movimento da criação do mundo vai da decisão rumo à palavra, da palavra rumo à ação, e da ação rumo à realidade criada. Neste movimento também a pessoa se conscientiza de si mesma como sendo criatura e imagem de Deus" (Moltmann, 1993, p. 352).

Por vezes, a pessoa se aprisiona em busca de possuir coisas, mas, nesse caso são as coisas que nos possuem, porque 
"Deus não nos fez para estas coisas frágeis e caducas, mas para as coisas celestes e eternas; não nos deu esta terra como nossa morada fixa, mas como lugar de exílio" (Leão XIII, 1891, $\mathrm{n}^{\circ}$ 11), é nesta perspectiva de que cabe ao ser humano pensar o futuro e a continuidade da Criação, que se pode pontuar sobre a práxis de vida e vivência da pessoa e sua relação com a família humana, de modo que este agir, deve acontecer de forma consciente, corrobora sobre o assunto Lovo, (2020, p. 6), ao salientar que:

Ainda sobre os conceitos de dominar, é possível enfatizar a atitude de conhecer plenamente a criação, para que assim o ser humano possa agir de forma prudente e responsável, na práxis da essência administrativa. É o esforço para manter a morada que empreende o humano, tendo em si a essência administrativa que o possibilita significar, submeter, 'cultivar e guardar O Jardim', enquanto cumpre a missão de 'ir e proliferar' (Gn 1,28).

Assim, tem-se que não importa a condição; o que é relevante para a edificação da vontade do Criador é a perspectiva do Reino, é essa decisão interior que nos aproxima do Criador e mesmo "que abundeis em riquezas ou outros bens, chamados bens de fortuna, ou que estejais privados deles, isto nada importa à eterna beatitude: o uso que fizerdes deles é o que interessa" (Leão XIII, 1891, nº 11).

É no matrimônio que se perdoa a cobiça do fruto proibido. O fruto proibido também era desejo que se apresentou na solidão original de Adão, e nisto se torna notória a citação de que "Uma das pobrezas mais profundas que o homem pode experimentar é a solidão" (Bento XVI, 2009, n 53). É dessa carne/osso que, se concebem filhos que agem na perspectiva do Reino, aqueles que soltam o fruto proibido, ou melhor, o que há de proibido em cada fruto, para se abraçarem à vontade do Criador, elevando o fruto, enquanto gratuidade que possibilita espaço e luz para outras criaturas.

A vida humana é fonte de esponsalidade com o Criador, e desta é a práxis sob a qual se administra e cocria a Casa Comum. Novamente se apresenta a corporeidade humana e se fundamenta que "o Verbo se fez carne, e habitou entre nós" (Jo 1,14) e habita entre nós, pois o ser humano é templo do Espírito Santo e, neste sentido, "de fato, a capacidade que o casal humano tem de gerar é o caminho por onde se desenrola a história da salvação" (Francisco, 2016, nº 11).

A capacidade de gerar filhos, "sede fecundos" (Gn 1,28) é a forma como o casal humano tem para dar continuidade à genealogia que se inscreve na biologia humana e, com isso, o casal "descobre a sua capacidade de transformar e, de certo modo, criar o mundo com o próprio trabalho, esquecendo que este se desenrola sempre sobre a base da doação originária das coisas por parte de Deus" (João Paulo II, 1991, n 37).

\subsection{Família: gesto que se realiza no trabalho}

Não se trata de um saber sobre a família, mas da relação cuidadosa e subsidiaria sob a qual as condutas e hábitos de viver a parentalidade, integram-se à família humana. É difícil compreender a vida cristã, quando se tem uma base intimista/fideísta/egolátrica e, nesse sentido, pode-se chegar à esterilidade da vida, quando se retira a 'ação' da 'ora-ação'.

A fé cristã é profundamente arraigada na relação e alteridade com o outro e é profundamente responsável por todos, ainda que, se "registra a presença de algumas culturas de matiz religioso que não empenham o homem na comunhão, mas isolam-no na busca do bem-estar individual, limitando-se a satisfazer os seus anseios psicológicos” (Bento XVI, 2009, $\mathrm{n}^{\circ}$ 55), por isso,

'Os indivíduos não nos aparecem desligados entre si quais grãos de areia, mas sim unidos por relações (...) orgânicas, harmoniosas e mútuas' e que, vice-versa, o homem não pode ser considerado 'simplesmente como um elemento e uma molécula do organismo social', cuidando destarte que à afirmação do primado da pessoa não correspondesse uma visão individualista ou massificada. (João Paulo II, 2004, nº 125)

Busca-se o sinal de uma autêntica economia da salvação, em que as possibilidades de uns, não signifiquem a ausência 
de subsídios às necessidades de outros, "no matrimônio, esta disponibilidade, embora aberta a todos, consiste particularmente no amor que os pais dedicam aos filhos" (João Paulo II, 1988, nº 21), a tal ponto que não é perseverante, amar ao próximo como a si mesmo, "sem a firme e constante determinação de empenhar-se em prol do bem de todos e de cada um, porque todos nós somos verdadeiramente responsáveis por todos" (João Paulo II, 2004, nº 43).

O ser humano é o Húmus da terra, alimentado sempre pelo Sopro Divino - Ruah - que possibilita a esponsalidade entre o Criador e sua criatura; com isso, o humano em família administra e cocria a Criação, "Porque o amor não é das coisas que se realizam ou se executam. Não está nunca dado, mas sempre a caminho de si mesmo" (Rahner, 1969, p. 202). O humano é sempre dependente de estar em esponsalidade, é nessa atitude que as nossas vidas estão em profunda comunhão. Continuamente, entra na minha existência a vida de outros mediante o que se pensa, diz, faz e realiza.

O Administrar é essência constitutiva do ser humano, é o despertar humano para posicionar-se diante das diversas possibilidades, e seu trabalho o faz diferente e correspondente para com o outro, e dá-lhe o significado enquanto sujeito e, dessa relação, realça-se a dimensão de economicidade que, diante de uma relação o edifica enquanto pessoa. Por isso, "Uma renovada 'teologia do trabalho' esclarece e aprofunda o significado do trabalho na vida cristã e determina o laço fundamental que existe entre o trabalho e a família, e, portanto, o significado original e insubstituível do trabalho da casa e da educação dos filhos" (João Paulo II, 1981, nº 23).

Quando se desenvolve teologia do trabalho, não se pode propor que o seu resultado tenha como endereço a linhagem sanguíneo-parental; o fruto do trabalho deve ter sempre como endereço a realização do projeto e da plenitude da vida, resguardado o direito à subsidiariedade dos filhos, ou seja, o trabalho, a casa, e a devida formação.

A princípio, tem-se o ser humano, totalmente independente, isolado e dono de tudo o que está a sua volta. Assim o é no ventre da Mãe, onde tudo se move de modo a proporcionar-lhe satisfação e cuidado, mas o sentido de ser o centro do mundo vai se perdendo, à medida que o bebê vai começando a desvencilhar-se de sua mãe, de tudo aquilo que lhe proporcionava segurança, e lhe garantia a vida.

A transcendência é uniforme durante a oportunidade de ser, na medida exata em que o ser humano descobre sua interioridade, e a descobre baseado na sua visão de exterioridade. É com o trabalho que pai e mãe realizam a oração (orar+ação) que proporciona qualidade de vida aos filhos, sem causar danos ao próximo, e a fraternidade que se realiza como resultado do trabalho humano.

\subsection{Converta-se ao cuidado ou às cifras monetárias}

O ser humano caminha ao não possibilitado e, mediante sua potência, desenvolve possibilidades, e o faz porque "considerem-nos os homens como servidores de Cristo e administradores dos mistérios de Deus. Ora, o que se requer dos administradores é que cada um seja fiel" (1Cor, 4,1-2). Assim, torna-se evidente que "A compreensão do homem torna-se mais exaustiva, se o virmos enquadrado na esfera da cultura, através da linguagem, da história e das posições que ele adota diante dos acontecimentos fundamentais da existência, tais como o nascimento, o amor, o trabalho, a morte.” (João Paulo II, 1991, nº 24).

Quando se abre à parentalidade, permite-se que os filhos administrem o futuro, não como entrega da vida, mas como participantes de uma nova lógica, agora com o novo ser gerado. Conceber um filho é participar do futuro. Enfatiza-se que Jesus não ensinou o ser humano a ser Deus, mas, a ser criaturas ungidas, e que essa unção se faz em práxis na perspectiva do reino, de tal forma que "a pessoa não pode encontrar plena realização somente em si mesma, prescindindo do seu ser 'com' $e$ 'pelos' outros” (João Paulo II, 2004, nº 165).

O projeto do Criador não está limitado à parentalidade, ao Estado, à sociedade, "mas abarca ordenadamente a humanidade inteira, de modo que ninguém se pode considerar alheio ou indiferente à sorte de outro membro da família 
humana" (João Paulo II, 1991, nº 51). Enseja-se, dessa forma, que se é a Nação dos filhos, cujos limites não são geográficos, mas a realização humana.

A vontade do Criador se faz mediante o agir humano, quando se tira a pessoa da cruz, e não quando o crucifica, "Ninguém pode afirmar que não é responsável pela sorte do próprio irmão (cf. Gn 4, 9; Lc 10, 29-37; Mt 25, 31-46)!" (João Paulo II, 1991, nº 51). Há que se notar que "não seria verdadeiramente digno do homem um tipo de desenvolvimento que não respeitasse e não promovesse os direitos humanos, pessoais e sociais, econômicos e políticos, incluindo os direitos das nações e dos povos" (João Paulo II, 1987, n 33).

A essência administrativa é práxis e, com isso, o humano é o autor do contexto socioeconômico, sob o qual acontece a vida e vivência humana "Hoje, talvez mais do que no passado, reconhece-se com maior clareza a contradição intrínseca de um desenvolvimento limitado só ao aspecto econômico" (João Paulo II, 1987, n 33). Um exemplo disso é que, "É inegável que as influências do contexto social sobre os estilos de vida são notáveis: por isso o desafio cultural que hoje o consumismo põe deve ser enfrentado com maior incisividade, sobretudo se se consideram as gerações futuras, as quais arriscam ter de viver num ambiente saqueado por causa de um consumo excessivo e desordenado." (João Paulo II, 2004, nº 360),

Todas as vezes que o humano se coloca em primazia, sobre uma de suas dimensões, afasta-se do projeto de desenvolvimento da pessoa, de tal forma que, "a verdadeira elevação do homem, conforme com a vocação natural e histórica de cada um, não se alcança só com o desfrute da abundância dos bens e dos serviços, ou dispondo de infraestruturas perfeitas" (João Paulo II, 1987, nº 33).

É preciso formar a consciência humana e não formar sistemas e estruturas econômicas, social e parental, um sistema de controle "impede de 'distinguir corretamente as formas novas e mais elevadas de satisfação das necessidades humanas, das necessidades artificialmente criadas que se opõem à formação de uma personalidade madura"” (João Paulo II, 2004, n 360). Quando há primazia dos aspectos econômicos, esse se torna um sistema de controle e "subordina facilmente a pessoa humana e as suas necessidades mais profundas às exigências da planificação econômica ou do lucro exclusivo" (João Paulo II, 1987, n $33)$.

A parentalidade é a unidade primeira da família humana, não é uma ferramenta do Estado, para preparar os futuros socializados. "Dorothee Solle observa que uma 'teologia política' precisa apenas admitir que, através de mudanças específicas nas estruturas sociais, 'o número de força que hoje compelem pecar pode ser diminuído"” (Sponheim, 1987, p. 453).

Não se pode condicionar a vida humana, à perspectiva de meros autômatos, porque "não é lícito do ponto de vista ético nem praticável menosprezar a natureza do homem que está feito para a liberdade" (João Paulo II, 1991, nº 25). Quando se obscurece a dimensão humana de economicidade, e se associa aos sistemas de controle econômico, é enfático que se geram injustiças e a primeira delas, é a desconsideração do ser humano.

Eis que é o ser humano, mediante a essência administrativa, propulsa a práxis que proporciona vida de acordo com os subsídios, as necessidades, e as possibilidades, isso é promover uma economicidade sob a perspectiva da prosperidade participativa e compartilhada. Neste sentido, cada pessoa é respeitada segundo seus dons e capacidade, e assim se faz a melhor vivência humana, no reino em contingência que se desenvolve, "Para contrastar este fenômeno é necessário esforçar-se por construir 'estilos de vida, nos quais a busca do verdadeiro, do belo e do bom, e a comunhão com os outros homens, em ordem ao crescimento comum, sejam os elementos que determinam as opções do consumo, da poupança e do investimento"” (João Paulo II, 2004, n 360).

Aqui reside um dos grandes problemas da humanidade - a capacidade de expressar-se, a tomar como princípio que o resultado do trabalho humano é sua forma ativa de expressão, desde que em um laço de esponsalidade com o Criador. O trabalho humano precisa ajudar a pessoa a expressar-se enquanto filhos, pessoas capazes de realizar segundo seus próprios dons. 
Muito da opressão que a avareza realiza na pessoa está na separação entre trabalho, parentalidade, família e perspectiva de administradores e cocriadores da Casa Comum. Na substituição do prazer criativo, administrativo e fraterno, por ganhos remuneratórios, suficientes para a sobrevivência, transforma-se o pão de cada dia em cifras monetárias.

\subsection{Administrar a família na família humana}

Percebe-se que a práxis tende a se direcionar ao processo transformador das pessoas em situação de vulnerabilidade, fomentando o agir que se direciona aos pobres e excluídos, "deixai vir a Mim os pequeninos e não os impeçais pois deles é o reino de Deus" (João Paulo II, 1981, n 26). O humano é, então, o ato administrativo na criação e, com isso, "o significado do agir humano no mundo, que é ligado à descoberta e ao respeito da lei natural que Deus imprimiu no universo criado, para que a humanidade o habite e guarde segundo o Seu projeto (cf. 2Pd 3,13)" (João Paulo II, 2004, n 37).

O humano que se abre ao Ser promove a harmoniosidade, é contemplativo e direciona todos ao caminho da verdade. O ser humano fomenta a práxis que forma uma cultura do acolhimento, da subsidiariedade e do bem comum, administrando e cocriando a criação; isso implica o zelo a si mesmo, à parentalidade, à criação e ao próximo, vivendo como família, na família humana.

O livro da Gênese nos propõe algumas linhas mestras da antropologia cristã: a inalienável dignidade da pessoa humana, que tem a sua raiz e a sua garantia no desígnio criador de Deus; a sociabilidade constitutiva do ser humano, que tem o seu protótipo na relação originária entre o homem e a mulher, 'união esta que foi a primeira expressão da comunhão de pessoas' (João Paulo II, 2004, nº 37).

Assim, o humano, quando se desvela como ser capaz de arbitrar vida a outro ser, realiza-se em conjugalidade (varão e mulher) que se unem definitivamente em esponsalidade com o Criador, na busca de uma sociabilidade que edifica a vida, ao mesmo tempo em que, reconhece o que dignifica a si.

Não é apenas, uma questão de abrir espaço a uma nova criatura humana, é preciso, a esponsalidade com o Criador. A união entre varão e mulher, o diálogo para que da semente que reside dispersa, no varão e na mulher, possa ocupar o vazio do ventre, assim é possibilitada a existência de um novo ser, a partir da concepção biológica, sob a qual acontece a genealogia que nos une em um só povo, a família humana.

A concepção deve acontecer no amor dos cônjuges, que celebram a atitude de ser pai/mãe na potência de ter filhos. Diante dessa realidade, há que se indagar, como se pode resolver a situação de que "nalguns países, muitos jovens "são frequentemente levados a adiar o matrimônio por problemas de tipo econômico, laboral ou de estudo" (Francisco, 2016, n ${ }^{\circ}$ ).

Aqui reside, ainda, a percepção de fragilidade que é o humano em sua infância, fato que alude à fragilidade da mulher para dar à luz, e em seus dias posteriores. Esse é um chamado para que o varão a acompanhe. Neste sentido, "Se alguém, possuindo os bens deste mundo, vê o seu irmão na necessidade e lhe fecha o coração, como permanecerá nele o amor de Deus? (1Jo 3,16-17)" (João XXIII, 1961, nº 158).

Atenta-se, ao fato da fragilidade da criança, que precisa de amparo e de condições para crescer e desenvolver-se, o pai e a mãe é para esta criança o ato administrativo e cocriador, e "Nisto conhecemos o Amor: ele deu a sua vida por nós. E nós também devemos dar a nossa vida pelos irmãos" (João XXIII, 1961, nº 158). Existe movimento próprio de que, varão e mulher, caminhem sobre os mesmos passos, para que os filhos possam compreender a existência e o Ser.

Ao doar-se a um o filho, que no ventre da mãe tudo recebe, e que em seus primeiros dias é acolhido, no carinho e aconchego do pai e da mãe, percebe-se que o pai é a completude da mãe, e ambos se esvaziam de forças para dar à luz, e que esse sentido de pertença tem um centro, um sentido de voltar ao início, que tudo lhe explica quanto à sua existência. Esses fatos ocorrem em um cenário que se pode assim definir, 
'Correndo o risco de simplificar, poderemos dizer que vivemos numa cultura que impele os jovens a não formarem uma família, porque privam-nos de possibilidades para o futuro. Mas esta mesma cultura apresenta a outros tantas opções que também eles são dissuadidos de formar uma família' (Francisco, 2016, nº 40).

Todavia, essa compreensão basta, enquanto infância, ao passo que a consciência o desperta a si mesmo, e cada pessoa começa a sentir o vazio, próprio do ser humano, 'solidão original' e, assim, a busca por explicações, é o primeiro sinal da essência administrativa, o Ser diante do que não lhe é possibilitado.

A infância, só pode ser compreendida, se revelada pelo pai/mãe, atitude fraternal de revelação. Assim, é a humanidade, carente de conhecimentos sobre a própria infância, princípio e origem, e as revelações predizem cada pessoa, com a própria importância que a finalidade sobre a qual se inicia a humanidade.

\section{Considerações Finais}

O ser humano é chamado a cuidar do Jardim, e neste se estabelecer enquanto família humana, assim, cada pessoa é o administrador e cocriador do Reino e se apresenta, enquanto possibilidade de amar ao próximo/outro e ser o ato administrativo à face humana. Toda a criação é um ato, que se perpetua por intermédio do agir humano às gerações. Neste sentido, se apresenta a parentalidade, enquanto unidade primeira da família humana.

A parentalidade é fonte que jorra sem cessar, banhando toda a família humana de cuidado, fraternidade e comunhão. Assim se apresenta que uma família que se fecha em si mesma, deixa de ser, no mundo, um sinal da presença da cultura do acolhimento. Toda família é, um gesto parental que se realiza, por intermédio do trabalho, em comunhão com toda a humanidade. Os grupos parentais, que se fecham em busca de explorar, de forma predatória a natureza e, nesta as pessoas que não pertencem a parentalidade. Por isso, todo projeto de parentalidade deve ser pensado à luz do projeto de Deus e, isso, implica reconhecer a economicidade e sociabilidade de todas as pessoas, para formar assim o núcleo, sobre o qual se administra a Criação.

Quando se enfatiza a passagem de que o ser humano não pode servir a dois senhores, se torna enfático todo o descontrole das sociedades que tem por objetivo servir às cifras monetárias. Para se pensar em um projeto de humanidade, respeito e alteridade é preciso se decidir ou, há uma conversão às cifras monetárias ou uma conversão ao cuidado.

É de se pontuar que, a globalização impõe ao ser humano os desafios de administrar as realidades da Casa Comum, mais que isso, é preciso que se possa agir e formar a consciência de pessoa em cada pessoa e, assim, compreender a necessidade de administrar a família/parentalidade na família humana. A parentalidade, o desejo de ter/ser família é o amor maior da comunhão humana, mas precisa ser pensado em esponsalidade com o Criador, deste modo, a parentalidade é família, à medida que se sente em família na família humana.

É preciso avançar no tema e narrar o agir humano enquanto fonte de desenvolvimento sustentável, neste sentido, é necessário garantir o desenvolvimento do ser humano como um todo envolvendo, principalmente, a economicidade, a sociabilidade e a parentalidade, essas dimensões são basilares para que se possa viver em uma sociedade que tenha como futuro a expectação de um mundo que garanta o bem comum, a subsidiariedade e a solidariedade como alicerces de acolhimento à toda pessoa.

\section{Referências}

Bento XVI. (2009). Caritas In Veritate. Roma: Libreria Editrice Vaticana.http://w2.vatican.va/content/benedictxvi/pt/encyclicals/documents/hf_benxvi_enc_20090629_caritas-in-veritate.html.

Bíblia. Português. (2012). Bíblia de Jerusalém. Nova edição revisada e ampliada. Paulus.

Braaten, E. C. (1987). Prolegômenos à dogmática Cristã. In: Braaten, Carl E.; Jenson, Robert W. (editores). Dogmática Cristã. Sinodal. p. 25-94. 
Bruner, J. (2002). Atos de significação. (2a ed.), Artmed.

Clandinin, D. J. \&Conelly, F. M. (2011). Pesquisa narrativa: experiências e história na pesquisa qualitativa. Tradução: Grupo de Pesquisa Narrativa e Educação de Professores ILEEL/UFU. EDUFU.

Francisco. (2015). Laudato Si'. Roma: Libreria Editrice Vaticana. http://w2.vatican.va/content/francesco/pt/encyclicals/documents/papafrancesco_20150524_enciclica-laudato-si.html.

Francisco. (2016). Amoris Laetitia. Roma: Libreria Editrice Vaticana. http://w2.vatican.va/content/francesco/pt/apost_exhortations/documents/papafrancesco_esortazione-ap_20160319_amoris-laetitia.html.

João Paulo II. (1981). Familiaris Consortio. Roma: Libreria Editrice Vaticana. http://w2.vatican.va/content/john-paulii/pt/apost_exhortations/documents/hf_jp-ii_exh_19811122_familiaris-consortio.html.

João Paulo II. (1987). Sollicitudo Rei Socialis. Roma: Libreria Editrice Vaticana. http://w2.vatican.va/content/john-paul-ii/pt/encyclicals/documents/hf_jpii_enc_30121987_sollicitudo-rei-socialis.html.

João Paulo II. (1988). Mulieris Dignitatem. Roma: Libreria Editrice Vaticana. http://w2.vatican.va/content/john-paul-ii/pt/apost_letters/1988/documents/hf_jpii_apl_19880815_mulieris-dignitatem.html.

João Paulo II. (1991). Centesimus Annus. Roma: Libreria Editrice Vaticana. http://w2.vatican.va/content/john-paul-ii/pt/encyclicals/documents/hf_jpii_enc_01051991_centesimus-annus.html.

João Paulo II. (1995). Evangelium Vitae. Roma: Libreria Editrice Vaticana. http://w2.vatican.va/content/paul-vi/pt/encyclicals/documents/hf_pvi_enc_25071968_humanae-vitae.html.

João Paulo II. (2004). Compêndio da Doutrina Social da Igreja. Roma: Libreria Editrice Vaticana. http://www.vatican.va/roman_curia/pontifical_councils/justpeace/documents/rc_pc_justpeace_doc_20060526_compendio-dott-soc_po.html.

João XXIII. (1961). Mater et Magistra. Roma: Libreria Editrice Vaticana. http://w2.vatican.va/content/john-xxiii/pt/encyclicals/documents/hf_jxxiii_enc_15051961_mater.html.

Leão XIII. (1891). Rerum Novarum. Roma: Libreria Editrice Vaticana. http://w2.vatican.va/content/leo-xiii/pt/encyclicals/documents/hf_1xiii_enc_15051891_rerum-novarum.html.

Lovo, O. A. \& Sanches, M. A. (2021). Dicotomia: visão da ação humana em Deus. Research, Society and Development, 10 (15), e538101523420. https://doi.org/10.33448/rsd-v10i15.23420

Lovo, O. A. (2020). Parentalidade: Administrar a Vida Humana. Revista De Cultura Teológica, Ano XXVIII (96). https://doi.org/10.23925/rct.i96.48682.

Lovo, O. A. (2021). Olhar à unidualidade do casal. In: Almeida, Flávio Aparecido de. (organizador). Ciências das Religiões uma análise transdisciplinar Volume 2. Editora Cientifica Digital, 176-192. https://doi.org/10.37885/210605002

Moltimann, J. (1993). Deus na criação: doutrina ecológica da criação. Tradução: Haroldo Reimer; Ivoni Richter Reimer. Vozes.

Rahner, K. (1969). Teologia e Antropologia. Edições Paulinas.

Sanches, M. A., da Rocha, V. B., \& Lovo, O. A. (2018). A influência da atividade profissional no planejamento familiar. Revista Caminhos - Revista de Ciências da Religião, 16(1), 230-242. http://doi.org/10.18224/cam.v16i1.6165

Sponheim, P. R. (1987). O pecado e o mal. In: Braaten, Carl E.; Jenson, Robert W. (editores). Dogmática Cristã. Sinodal. 359-454. 